\title{
Intersticinių plaučių ligų morfologija
}

\author{
Valdas Šarauskas, Dovilè Baltraitė \\ LSMU MA Patologinès anatomijos klinika
}

Reikšminiai žodžiai: intersticinės plaučių ligos, iprastinė intersticinė pneumonija, nespecifinè intersticinè pneumonija, kriptogeninè besiorganizuojanti pneumonija, ūminè intersticinė pneumonija, limfocitinè intersticinė pneumonija, morfologija, diagnostika.

Santrauka. Intersticinės plaučių ligos - tai klinikinejje praktikoje santykinai reta heterologinè grupé ligų. Etiologija dažniausiai tiksliai nežinoma ir gali būti lemiama daugybės veiksnių. Intersticinės plaučių ligos taip vadinamos dèl joms būdingo uždegimo ląstelių pagausẻjimo ir susikaupimo, taip pat dèl jungiamojo audinio išvešèjimo plaučių intersticiniame audinyje. Atskiros intersticinès plaučių ligos dažnai esti tarpusavyje panašios tiek pagal klinikinius, tiek pagal radiologinių tyrimų duomenis. Tiksliai diagnostikai dažniausiai prireikia operacinės medžiagos - biopsinės medžiagos nepakanka. Siekiant tikslios diagnostikos, adekvataus gydymo ir ligoniui palankios prognozės, turi būti užtikrintas įvairių sričių specialistų bendradarbiavimas.

Intersticinès plaučių ligos (IPL) - tai daugialypè grupé plaučiu ligų, dar kitaip apibūdinamų „infiltracinėmis ar restrikcinèmis", kurioms būdinga uždegimo ląsteliu pagausėjimas ir susikaupimas, taip pat jungiamojo audinio išvešèjimas plaučių intersticiniame audinyje. Atskiros intersticinès plaučių ligos dažnai esti panašios tiek pagal klinikinius, tiek radiologinius požymius. IPL eiga gali būti ūminè ar lètinè, jụ prognozè labai įvairi.

\section{IPL KLASIFIKACIJA}

- Aiškios etiologijos IPL: susijusios su sistemine jungiamojo audinio liga, žalingais profesiniais veiksniais, vaistu vartojimu, infekcija, dèl pasikartojančios aspiracijos, lètinių plaučių ligų (bronchektazès, cistinè fibrozè, lètinè obstrukcinè plaučiu liga, astma).

- Idiopatinè intersticiné pneumonija: idiopatiné plaučiu fibrozè, nespecifinè intersticinè pneumonija, kriptogeniné besiorganizuojanti pneumonija ir kt.

- Granuliominès plaučių ligos: sarkoidozè, egzogeninis alerginis alveolitas ir kt.

- Kitos - eozinofiliné pneumonija, plaučiu limfangiolejomiomatozé, plaučiu Langerhanso ląsteliụ histiocitozè, alveolinè proteinozè ir kt.

\section{SĖKMINGOS MORFOLOGINĖS DIAGNOSTIKOS PRINCIPAI}

- Didesnès dalies patologijos diagnostikai nepakanka bronchoskopiškai paimtos medžiagos. Reikia operacinès medžiagos iš informatyviư plaučių vietų, pageidautina bent $1 \mathrm{~cm}^{3}$.

- Daug naudos duoda atidus tyrimas mikroskopu mažai padidinus.

- Tiksli intersticinio pažeidimo vieta: centrinè acinarinè (peribronchiolinè), perivenozinè, subpleurinè intersticinè, alveolinè, kraujagyslių.

Komandinis darbas ženkliai palengvina morfologinę diferencinę diagnostiką.

\section{İPRASTINĖ INTERSTICINĖ PNEUMONIJA (IIP)}

Tai neaiškios kilmės, blogos prognozės lètinė intersticinè plaučių liga.

Makroskopiškai plaučiai nedaug sumažèję. Fibrozè ryškesnè apatinėse skiltyse, subpleurinėse srityse ir palei tarpskiltines pertvaras. Audiniui randejant, plautis išoriškai primena cirozès pažeistas kepenis, pjūviuose - fibrozė, korètumas. Histologinis IIP vaizdas he- 
terogeniškas: saiki limfocitinė intersticinė infiltracija ir įvairaus laipsnio intersticinė fibrozè greta išlikusių normalaus plaučių audinio sričių (1 pav.). Būdingas nevienodas laiko atžvilgiu pokyčiuc progresavimas: fibroblastų proliferacija šalia randinio skaidulingo fibrozinio audinio, intersticinè fibrozè su neryškiu intersticiniu uždegimu, „korètoji“ fibrozè. Kraujagyslèse galima pastebèti intimos fibrozę, medijos išplonèjimą, kas siejama su plautinès hipertenzijos atsiradimu. IIP nebūdinga CD1a teigiamos histiocitinès ląstelès, granuliomos, asbesto kūneliai, kitos neorganinès medžiagos, ryški eozinofilija ar ryški limfocitine intersticinė infiltracija. Mikroskopinis vaizdas nèra patognominis šiai ligai, IIP reikia atskirti nuo asbestozès, kolageninių kraujagyslių ligų, EAA, spindulinio pneumonito, bronchektazinès ligos, sarkoidozès, toksinio vaistų poveikio sąlygotos patologijos [1, 3].

\section{NESPECIFINE் INTERSTICINE் PNEUMONIJA (NSIP)}

Patologija, susijusi su kolageninėmis ligomis, vaistų sukeltu pneumonitu, infekciniais procesais, ŽIV sąlygotu imunodeficitu, egzogeniniu alerginiu alveolitu. Kartais aiškios priežasties nèra (idiopatinè NSIP).

Skiriami du morfologiniai tipai: ląstelinis ir fibrozinis, pastarasis blogesnès prognozès (persidengia su IIP). Histologiniai NSIP požymiai: lengvo ar vidutinio laipsnio lètinis intersticinis uždegimas, II tipo pneumocitų hiperplazija uždegimo pažeistose srityse; lengvo ar vidutinio laipsnio intersticinè fibrozè, vienodas vaizdas visose srityse, nèra židininio pasiskirstymo; besiorganizuojanti pneumonija neryški, gali būti tik židininių pokyčių, nèra pažeidimų heterogeniškumo, neturètų būti fibroblastų proliferacijos, eozinofilai tik keli arba jų visai nèra, nèra granuliomų, nebūdingi virusiniai intarpai ar mikroorganizmai (patvirtinama dažymo metodais) [1].

\section{KRIPTOGENINĖ BESIORGANIZUOJANTI PNEUMONIJA (KOP)}

Pažeidimų etiologija nežinoma. Histologiškai audinys nevienodas dèl besiorganizuojančios fibrozès ir dèl lètinio uždegimo susidariusios uždegimo ląstelių infiltracijos viršutinėse kvėpavimo takų dalyse. Pažeidimo pobūdis margas, greta išlikę nepažeisto audinių plotų. Spindžiuose besiformuojanti fibrozė užkemša bronchioles, alveolinius latakus ir aplinkines alveoles. Būdingas vienodas laiko atžvilgiu pažeidimo progresavimas. Alveolinės pertvaros tik šiek tiek išplonėja, matyti intersticinis lètinis uždegimas, švelni II tipo pneumocitų hiperplazija. Vaizdas nèra specifiškas, panašių pokyčių gali būti esant kitos etiopatogenezès plaučių pažeidimo atvejais (infekcijos, infarktai, neoplazmos, abscesai, hemoragijos), todèl diagnozę reikètų gristi atsižvelgiant ir $\mathfrak{i}$ anamnezę, klinikinius ir kitų tyrimų duomenis [2].

\section{ŪMINĖ INTERSTICINĖ PNEUMONIJA (ŪIP)}

Liga yra etiologiškai susijusi su uremija, infekcija, vaistų toksiškumu, toksinėmis inhaliacijomis, sepsiu, šoku, trauma, kolageninemis ligomis, transfuzijomis.

Morfologinis vaizdas difuzinis, pažeidimas progresuoja vienodai laiko atžvilgiu. I tipo pneumocitai suyra, atsidengia pamatinès membranos. Būdingos hialininès membranos, susidariusios iš kraujo ir suirusių alveoliocitų citoplazmos bei branduolių liekanų (2 pav.). Ketvirtą penktą parą hialininès membranos matomos geriausiai. Alveolių pertvaros sustorèja. Vèlyvesnèse stadijose būdinga oro tarpų susidarymas, cistinių darinių formavimasis, kai kuriais atvejais plaučių hipertenzija $[1,3,4]$.

\section{LIMFOCITINE் INTERSTICINE் PNEUMONIJA (LIP)}

Reta patologija, galinti būti idiopatinè ar susijusi su infekcija, kolageninėmis kraujagyslių ligomis, imunodeficito būkle, autoimunine hemolizine anemija, vaistų sukelta patologija ir kt.

LIP būdinga difuzinė intersticinė nemonokloninė limfocitinè infiltracija plaučiuose, pažeidimas alveolių sienoje ne pagal limfagysles (kas labiau būdinga limfomoms), T limfocituc, plazmocituc, makrofagų infiltracija, peribronchinè limfoidinè hiperplazija [4].

\section{DESKVAMACINE் INTERSTICINE் PNEUMONIJA (DIP) IR SU RESPIRACINIU BRONCHIOLITU SUSIJUSI INTERSTICINE PLAUČIŲ LIGA (RBIPL)}

Abiejų šių ligų pagrindinis etiologinis veiksnys yra rūkymas.

Deskvamacinei intersticinei pneumonijai būdingi difuziškai išsidèstę gausūs makrofagai su rudu pigmentu alveolèse (3 pav.), kvėpuojamosios bronchiolès neinfiltruotos, alveolių pertvaros kiek sustorejjusios. Tai restrikcinis pažeidimas, obstrukcijos nèra [4].

Respiraciniam bronchiolitui būdingas audinio margumas, centrinis išsidèstymas kvėpuojamosiose bronchiolèse, alveolių latakèliuose gausios sankaupos rudų makrofagų, fagocitavusių rūkalų šalutinius produktus. Kliniškai RBIPL pasireiškia obstrukcija ir restrikcija. Vèlyvesnèse stadijose progresuoja peribronchiolinè fibrozè, plaučių audinio destrukcija, emfizema. Ligos prognozè - itin palanki nustojus rūkyti, nes susidarę pokyčiai per tam tikrą laiką regresuoja [4].

\section{EGZOGENINIS ALERGINIS ALVEOLITAS (EAA)}

Liga prasideda kaip imuninis organizmo atsakas (III, IV tipo hipererginė reakcija) i išorinius antigenus, kurių patenka i organizmą kvėpuojant. Yra daugybė medžiagų, galinčių sukelti organizme panašias reakcijas, tačiau dažnai ligos priežastis vis dèlto lieka ne- 


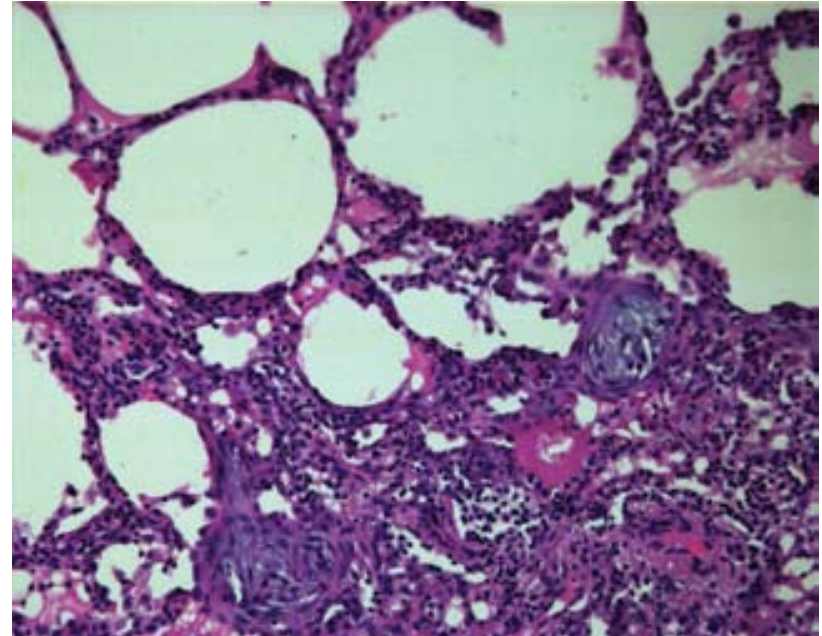

1 pav. Šalia normalios struktūros plaučių audinio matomi jaunų fibroblastu telkiniai

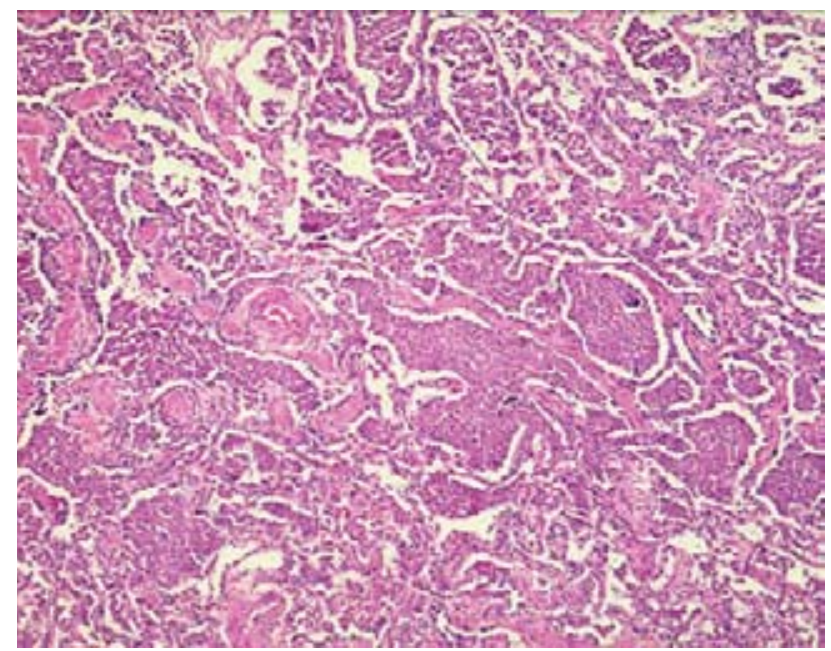

3 pav. Gausūs intraalveoliniai siderofagai

aiški. Kai kurie antigenai aptinkami tam tikroje, tik jiems būdingoje aplinkoje, todèl praktikoje gali būti vartojami specifiniai ligu pavadinimai, pvz., „fermerio plaučiai" ir kt.

Morfologiškai ūminiam alerginiam alveolitui būdinga neutrofiluc infiltracija alveolèse ir kvėpuojamosiose bronchiolèse. Lètinès eigos EAA būdinga įvairaus laipsnio limfocituc, makrofagų, negausių plazmocitų, eozinofiliniu granuliocitu infiltracija i intersticini audinị ir nenekrozinès granuliomos plaučių periferinèse dalyse, formuojamos citotoksinių $\mathrm{T}$ limfocituc, epitelioidinių bei daugiabranduolių ląstelių. Vèlyvesnèse ligos stadijose infiltracija mažèja, vietoje jos atsiranda nespecifinè intersticinè fibrozè. Histologiškai EAA piešinys nèra specifinis, diagnostikai itin svarbi paciento anamnezè $[1,2,3]$.

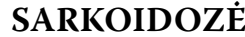

Neaiškios etiologijos sisteminè liga, kuriai būdingas granuliomų formavimasis įvairiuose organuose. Dia-

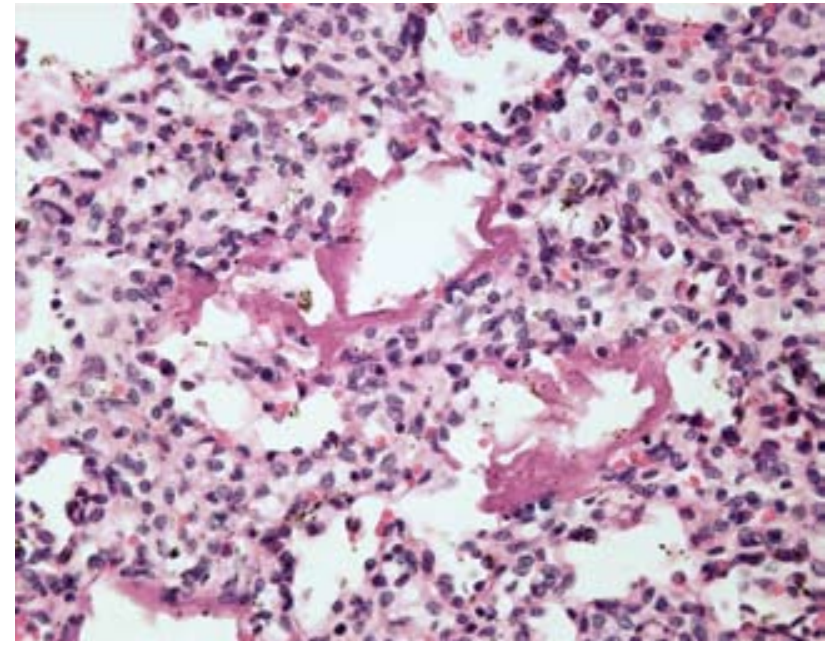

2 pav. Hialininès membranos alveolių spindžiuose bei atsilupę alveoliocitai

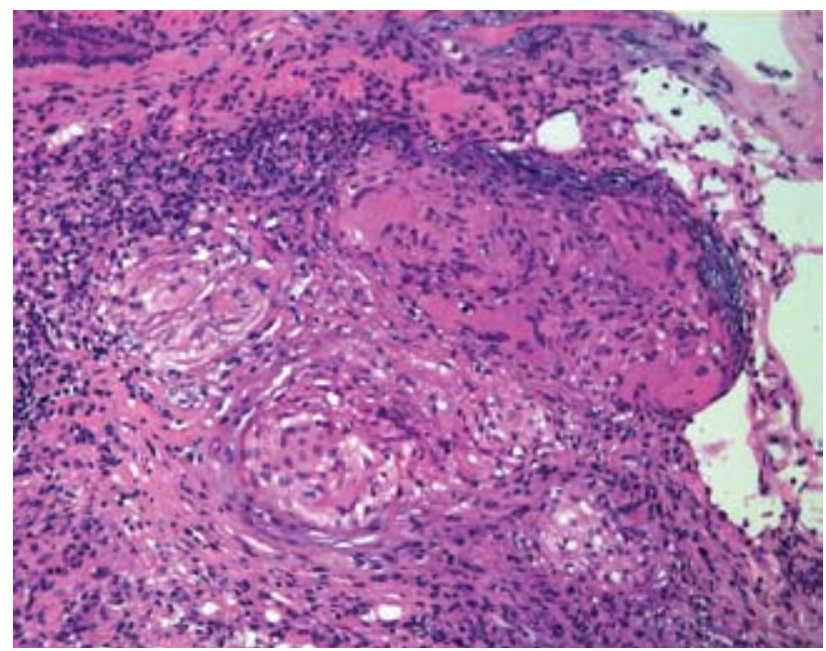

4 pav. Nenekrozinės granuliomos, sudarytos iš epitelioidiniu, daugiabranduolių ląstelių ir pavienių limfocitų

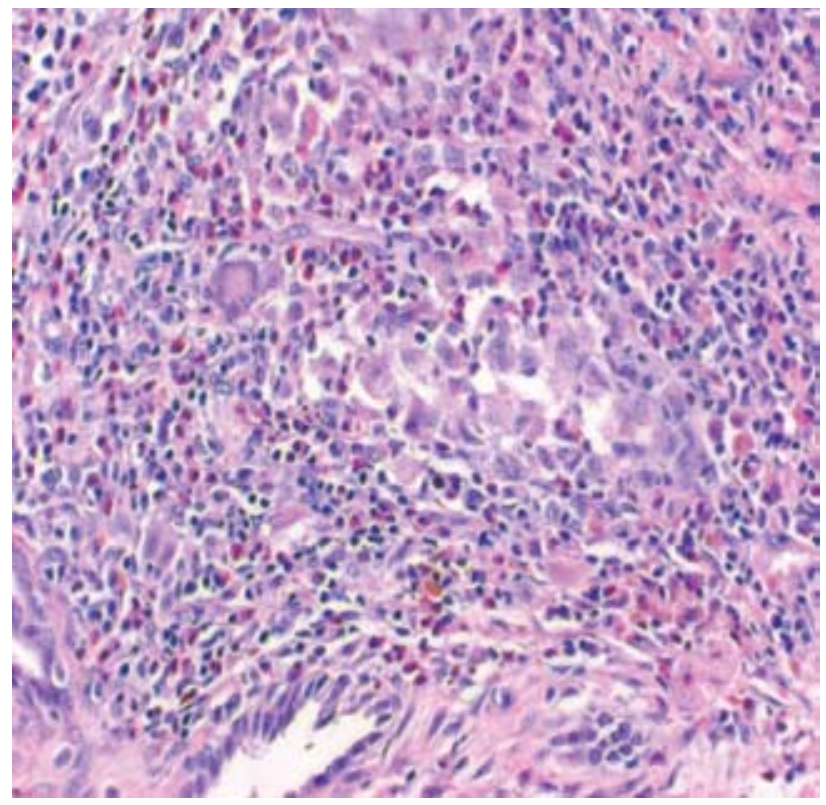

5 pav. Dentritinès Langerhanso ląstelès ir gausūs eozinofiliniai granuliocitai tarp ju 
gnozuojama dažniausiai tada, kai plaučių pažeidimai būna jau labai pažengę. Prognozè palanki, miršta mažiau nei 3 proc. ligonių.

Histologiniu tyrimu bioptate nustatoma granuliomų, sudarytų iš epitelioidinių ir gigantinių daugiabranduolių ląstelių, be kazeozinès nekrozès (smulkių nekrozès plotuc gali būti) (4 pav.). Bronchų ir alveoliu nuoplovose vyrauja limfocitai. Būdinga granuliomų išsidèstymas išilgai limfinių takų, granuliominis vaskulitas. Pirmiausia pažeidžiama pleura, jungiamojo audinio pertvaros ir intersticinis audinys apie kraujagysles ir bronchus. Granuliomos mažos, pavienès arba formuojančios konglomeratus, sudarytos iš epitelioidinių histiocituc ir daugiabranduolių gigantinių ląstelių. Histiocitai išsidèstę labai glaudžiai ir aiškiai atskirti nuo aplinkinio audinio. Aplink išsidèstę kolageno sluoksniai, dèl kurių bendras vaizdas primena svogūno sluoksnius. Granuliomos viduje dažnai būna keli limfocitai, vyrauja CD4 ląstelès, o aplink jas - pavieniai CD8, B limfocitai $[1,4]$.

\section{VEGENERIO GRANULIOMATOZE}

Uždegimo kilmès viršutinių kvẻpavimo takų ir plaučių bei inkstų pažeidimas. Histologiškai nustatoma granuliomatozė ir vaskulitas. Viduje granuliomų susidaro kolikvacinė (fibrininè) nekrozè (rožinès spalvos beformè masè, branduolių liekanos, uždegimo ląstelès), o aplink ją telkiasi histiocitai su gigantiškomis ląstelèmis. Uždegimo substratą sudaro limfocitai, plazmocitai, daugiabranduoliai leukocitai ir nedaug eozinofilų. Granuliomos kampuotos formos. Matyti vaskulitas kraujagyslių sienelès edemiškos, infiltruotos uždegimo ląstelių. Fibrinoidinè nekrozè kraujagyslèse yra patognominis Vegenerio granuliomatozès simptomas $[1,3,4]$.

\section{LANGERHANSO LĄSTELIŲ HISTIOCITOZE் (LH)}

Skiriami du tipai: mazginis ir difuzinis. Difuzinès LH išsivystymo priežastis yra rūkymas.

LH būdinga emfizeminiai plaučių audinio pokyčiai, dentritinès kilmès Langerhanso ląstelių sankaupos apie vidutinius bei smulkiuosius kvejpavimo takus, iš Langerhanso ląstelių, makrofagų ir eozinofilinių granuliocitų susidarę mazgeliai, bronchiolių destrukcija bei progresavimas ị fibrozę be Langerhanso ląstelių. Langerhanso ląstelių skiriamieji bruožai: citoplazminès
Birbecko granulès (nustatomos elektroninès mikroskopijos metodu), C3, IgG-Fc receptoriai, teigiamos reakcijos su imuniniais žymenimis S100, CD1a (reakcija su CD68 neigiama) $[1,4]$.

\section{LIMFANGIOLEJOMIOMATOZE் (LAM)}

Retai pasitaikanti liga. Serga jaunos, reprodukcinio amžiaus moterys. Patologija dažniausiai susijusi su inkstų angiomiolipoma, šviesiųjų ląstelių plaučių navikais, odos, širdies navikais. Kilmè nežinoma. Būdinga pneumochiliotoraksai ir kraujo atkosejjimas. Ligos eiga gali būti greitai arba lètai progresuojanti. Tinkamiausias gydymo metodas - plaučių transplantacija.

Neįmanoma ligos diagnozuoti atliekant citologinị tyrimą. Mikroskopiškai vaizdas abipus difuzinis su cistiniais pokyčiais, primenančiais emfizemą. Histologiškai nustatoma išplitusi nebrandžių ovalios ar verpstès formos lygiụjų raumenų ląstelių proliferacija intersticiume, plaučių limfmazgiuose, stambiuose limfiniuose latakuose tarpuplautyje. Susidaro daugybè cistinių tarpų šalia nenormalių lygiųjų raumenų pluoštų. Kraujagyslių sienos taip pat gali būti infiltruotos, dèl to susidaro mikroskopinès hemoragijos, alveolèse susikaupia hemosiderofagai. Lygiųjų raumenų ląstelès teigiamai reaguoja su HMB-45, lygiụjų raumenų aktinu, desminu. Kartais LAM ląstelèse gali būti estrogenų ar progestinų receptorių $[1,4]$.

\section{MORPHOLOGY OF INTERSTITIAL LUNG DISEASES}

\section{VALDAS ŠARAUSKAS, DOVILE BALTRAITÉ \\ DEPARTMENT OF PATHOLOGICAL ANATOMY LITHUANIAN UNIVERSITY OF HEALTH SCIENCES}

Keywords: interstitial lung diseases, usual interstitial pneumonia, nonspecific interstitial pneumonia, cryptogenic organizing pneumonia, acute interstitial pneumonia, lymphocytic interstitial pneumonia, morphology, diagnosis. Summary. A large number of pulmonary disorders grouped as interstitial are relatively rare. An etiology usualy unknown. They have no specific symptoms and are characterized by inflammatory infiltrates in the intersticial space and have similar clinical and radiological presentations. For this reason biopsy often is not enough, accurate diagnosis require examination of operating materials. Difficult diagnosis of these disorders leads to multidisciplinary team work, which can ensure effective treatment and favorable prognosis.

\section{LITERATŪRA}

1. Rubin E, Farber JL, editors. Pathology. Third edition. Philadelphia: Lippincott-Raven Publishers; 1999.

2. Kumar V, Abbas AK, Fausto N, Aster JC, editors. Robbins and Cotran pathologic basis of disease. Eighth edition. Philadelphia: Elsevier; 2010.

3. Sternberg SS, Antonioli DA, Carter D, Mills SE, Oberman HA, editors. Diagnostic surgical pathology. Third edition. Volume 1. Philadelphia: Lippincott-Raven Publishers; 1999.

4. Popper $\mathrm{HH}$, course director. Lung, pleural and mediastinal diseases. Handout part I.-II Graz; 2010. 